\title{
French inquiry into misconduct is shelved
}

[PARIS] The French government has quietly dropped plans to commission an international inquiry into allegations of misconduct at a laboratory of INSERM, the national biomedical research agency (see Nature 393, 203; 1998).

In May, Daniel Nahon, the directorgeneral of the Ministry of National Education, Research and Technology announced that four international experts would be asked to carry out an inquiry into the activities of the INSERM Laboratory of Nutrition, Lipoprotein Metabolism and Atherosclerosis at the University of Rennes 1 , and its director Bernard Bihain (see Nature 391, 519-520 $\& 825$; 1998). He promised that the inquiry would be completed within three months and its conclusions made public.

The laboratory itself was closed by INSERM in August on the grounds that Bihain had asked to be discharged from his duties on "personal grounds". At the time, many scientists expressed concern that the closure might be used to justify a reduction in efforts to get to the bottom of the affair.

Their fears appear to have been realized.
Nature has learnt that the ministry has now abandoned the inquiry. "We stopped everything," admits Vincent Courtillot, principal adviser to Claude Allègre, the science minister. "The affair is over, the guy is in America, the lab does not exist, so we are not going to make an inquiry committee work on something where there are no consequences."

Jacques Lenfant, vice-chancellor of the University of Rennes I, says he is deeply disappointed by the government's action, and questions why it began an inquiry in the first place. The scientific board of INSERM has also repeated its demand that a scientific investigation of the laboratory be carried out and made public "in the interests of the agency and its staff".

For its part, the SNTRS-CGT, a trade union representing INSERM scientists, has called for "full light to be thrown on the presumptions of scientific fraud", arguing that "the honour of the scientific community is at stake".

In a thinly veiled allegation that the government has tried to hush-up the affair, it asserts that "only the decision-makers had to be worried about the outcome of a search for the truth".

Meanwhile, a separate inquiry into the activities of the laboratory by the police fraud squad in Rennes (see Nature 394, 308; 1998) has moved a step closer to becoming a formal judicial inquiry. The public prosecutor of the region has opened a preliminary investigation into the affair, following the submission of an 'information file' ('dossier de renseignement') by the fraud squad making the case for a judicial inquiry.

INSERM, which has been widely criticized over its handling of the Bihain affair, is to create an office of scientific integrity. Claude Griscelli, the agency's director-general, says the unit's remit will be to investigate "promptly and effectively" all allegations of misconduct, and to settle disputes, for example over the order of authorship on papers.

In a bid to prevent future misconduct, the unit will also make recommendations for good laboratory practice. These would include guidelines for clinical trials and standards for keeping laboratory note-books and other records. Declan Butler

\section{Controversial Sw edish science minister loses seat in reshuffle}

[Sтоскноцм] A cabinet reshuffle in Sweden has led to the demotion of its controversial science minister, Carl Tham, who had angered many influential members of the scientific community with sweeping changes to higher education and research.

In his four years as science minister, Tham redirected funding from basic to applied research, with increased emphasis on the interaction between science and society, including closer cooperation between science and industry.

Tham had also expressed a desire to reform power structures within the academic research community, breaking down interdisciplinary barriers and giving minority groups greater access to both higher education and research.

Tham lost his post in a reshuffle earlier this month following a general election in which support for the ruling Social Democrats fell by 11 per cent, although they continue to govern with support from the former communist party and the Greens. Tham has been replaced by Thomas Östros, the former tax minister.

No official reason has been given for the change. But Tham had faced a growing band of critics as he moved to increase political influence over the allocation of resources and decisions about research priorities, challenging the traditional autonomy of the universities.

The traditional academic hierarchy also opposed Tham's reforms to substantially increase the numbers of professors at universities by giving this title to former senior lecturers.

Tham also established several new, regional universities, reallocating money to them from the established universities, and gave a number of smaller and regional universities the status of 'complete' universities.

Furthermore, 30 new professorships in various subjects have been created, earmarked for specified groups, particularly women. A number of new posts in 'gender research' were also established, and reforms introduced to speed up the passage of students through higher education.

Tham's reforms have met with considerable support from those who have benefited from them, such as the feminist movement and representatives of the regional universities. But they have also generated repeated protests from large sectors of the scientific community.

Shortly before last month's general election, for example, more than 300 professors of medicine, natural sciences and technology signed a public protest against the reallocation of money from basic to applied research.

"What has taken decades to build up is about to be lost," says Dan E. Nilsson, professor of zoology at the University of Lund, who initiated the protest. "We need

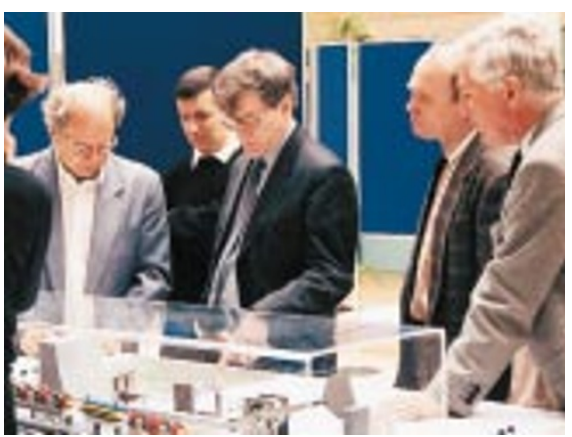

Tham (centre), seen here on an official visit, has faced growing criticism of his radical policies.

quick and forceful reactions to keep Sweden at the forefront of science."

Dan Brändström, head of The Bank of Sweden Tercentenary Foundation, one of the country's largest independent sources of science funding, says it is important to rebuild confidence between science and politics. "Diplomacy, dialogue and respect for the problems that science is facing during a time of restructuring is what we hope for from the new minister," he says.

But whether the appointment of the new minister will lead to any real change in policy remains to be seen. Sweden's prime minister, Göran Persson, has declined to make any public criticism of his former science minister. This suggests that, even though Tham has left, the policies he introduced may remain in force.

Peter Sylwan 